Editorial

\title{
"It's All about Working with the Story!": On Movement Direction in Musicals. An Interview with Lucy Hind
}

\section{George Rodosthenous}

School of Performance and Cultural Industries, University of Leeds, Leeds LS2 9JT, UK; g.rodosthenous@leeds.ac.uk

Received: 22 April 2020; Accepted: 28 April 2020; Published: 30 April 2020

check for updates

\begin{abstract}
Lucy Hind is a South African choreographer and movement director who lives in the UK. Her training was in choreography, mime and physical theatre at Rhodes University, South Africa. After her studies, Hind performed with the celebrated First Physical Theatre Company. In the UK, she has worked as movement director and performer in theatres including the Almeida, Barbican, Bath Theatre Royal, Leeds Playhouse Lowry, Sheffield Crucible, The Old Vic and The Royal Exchange. Lucy is also an associate artist of the award-winning Slung Low theatre company, which specializes in making epic theatre in non-theatre spaces. Here, Lucy talks to George Rodosthenous about her movement direction on the award-winning musical Girl from the North Country (The Old Vic/West End/Toronto and recently seen on Broadway), which was described by New York Times critic Ben Brantley as "superb". The conversation delves into Lucy's working methods: the ways she works with actors, the importance of collaborative work and her approach to characterization. Hind believes that her work affects the overall "tone, the atmosphere and the shape of the show".
\end{abstract}

Keywords: choreography; dance; direction; creative team; collaboration; musicals; rehearsals; movement; movement direction

\section{Choreography or Movement Direction?}

George Rodosthenous (GR): Thank you for joining us today for a discussion about your work on the award-winning Girl from the North Country. Can I just start by asking you to clarify any differences you see between choreography and movement direction in musical theatre?

Lucy Hind $(L H)$ : The main difference is that movement direction encapsulates the whole movement language of the show, and that can be everything from body coaching the actors to building character, the scene changes, as well as the physical landscape of the show. So, everything from the tone with which people move through a space, right to and including the choreography. In a musical, that's obviously all the dance steps, but also, if it's not a musical, there could be a small amount of dance, let's say a Shakespeare play with an Elizabethan dance. Or, if it's a straight play and there is a little moment where two characters dance together, that could be classed as choreography, but as it is a play, it would likely be billed as movement direction.

For me, it all very much depends on the audience and how they will understand and experience your work in the show. In Girl from the North Country I was billed, and still am, as movement director and some of the press in the USA were puzzled about who did the choreography, but acknowledged that I was billed as movement director. So, it very much depends on who will be watching the show. And also, it depends on the relationship between the director and the movement director.

My experience as a movement director, as opposed to going in as a choreographer on something like an opera, is that as movement director, we stand shoulder to shoulder with the director and we 
create the show together. And that's not to say I do any of the director's job for them, but we create the tone, the atmosphere and the shape of the show together-side by side. It's a very close collaboration with the musical director as well. But everybody's experience is likely to be different.

GR: Lauren Pattullo writes that "The genre of the Hollywood musical is defined by shifts between plot and number, narrative and spectacle. Busby Berkeley and Gene Kelly provide examples of two different methods of handling these shifts. These can be described as aggregation and integration. The former is exemplified in the work of Berkeley through the use of the backstage format, which allows for the separation of narrative and number into two worlds: offstage and onstage. In contrast, Kelly's integrated approach gives dance a narrative function, which results in the inseparability of number and narrative within the film" (Pattullo 2007, p. 78). Does your movement direction enhance the narrative development? In what ways do you see movement enhancing narrative?

$L H$ : There are many different ways to approach movement in a show, but I hope the purpose of my work is to enhance narrative development. It's all about working with the story, and the characters and the actors you have in front of you to drive the narrative forward, unpick it, add to it, colour it in. I know a lot of movement directors and choreographers who work very differently. My specific work is always about story. I spend a lot of time telling actors "Please stop dancing"! or "Please stop demonstrating". And if there are any moments where it feels like it's movement for movement's sake or the choreography or dance moves stand apart from the story, you know immediately when it's not truthful. It's all about truth-it's about connecting the bodies with the story. That does not mean a copy abstract. It needs to fit with the world and the telling of the story. If the poetry of the language feels abstract or otherly, or even otherworldly, then there is absolutely space for a more abstract movement language within that.

\section{GR: What does it offer to a production?}

LH: Everything has to be connected-joining up those dots, finding those characters' physical offerings with scene changes, finding ways to tell a part of the story without language, and how that all seamlessly fits together is very important part of the show. I feel it's like the roots of the production, but also the gloss that goes over the top. It has to be in from day 1 , when you are meeting those bodies and you are finding what they have to offer, and you are building up a landscape. And then, as well, on the top, it's the shine-it's the broad sweeps, the macro- and the micro-choreography.

GR: How do you work with the documentation in terms of revival or continued choreographic invention?

$L H$ : In terms of documenting my own work, I learnt a lot when I went to America, because they insist on a very thorough "Bible", and I was quite intimidated by it, at first. I had never documented my work like that before, because I don't ever want direct replications of my work. That sounds strange, but if a new actor takes on a role, I will almost certainly remake the movement for that actor. I have had associates take over choreography for me, and I have taken them through the process and they know my work incredibly well. So, they will often teach the basics of what the moves were before, and then they will find ways to fit that particular actor. I am not precious about particular steps. I wouldn't say I have signature moves, but, what I have is something, if you look at something, it's the way it makes you feel. That can't be necessarily documented.

In Girl from the North Country, what we have is a "Bible" where I absolutely drew in and noted everything. It was in the forms of diagrams and things listed according to the music-for songs, it was choreography in my own words, with the counts listed to next to it. I don't use a particular type of notation.

In the number "Hurricane", every single member of company is doing a different set of moves at any one time- and there are 18 of them on stage. There are some very near misses, it's very tightly shaped, but there are only a couple of phrases in each of the choruses that they do a bit of unison. So, documenting that is incredibly difficult. Every time I get a new cast, and I have made it five times now, I re-make that number from scratch. I know the structure of it. I know the form of it. And then, I work 
with every single individual actor and I know their track and at what moment they have anchor points. It's difficult and it's hard to pass on, but I am always there to re-make my own work. I always love it and request to do so. As time goes on, who knows how that will happen?

GR: In his review for Girl from the North Country, Ben Brantley exclaimed that "Lucy Hind's movement direction is superb" (Brantley 2018). What are your working methods when you worked with the Bob Dylan songs?

$L H$ : When I worked with Bob Dylan songs on that particular show, I collaborated with the director and writer Conor McPherson, Simon Hale (who did the orchestrations and arrangements) and Rae Smith (the designer). With the four of us working together, I felt I was on a team in rehearsals like I've never been before. We had no idea what that show was. It was not in a traditional form, the songs did not relate to the script; we moved them around, we chopped them up, we stuck them together, we experimented and we had the luxury of some amazing time together. We played and played and played. The thing I learnt most from that show is that, in my moments of stress or wanting some structure-wanting some answers in the fear, when your ego gets in the way and you go "But is it any good?"-Conor would go "We will know it when we see it". I hold onto that so close everyday in my work now. The moment when you have to just trust that experience and gut-feeling or knowing if something is truthful: deep down feeling it.

We would listen to a number (they would learn it and we would sit next to each other) and I would say "What do you think this is?" and sometimes he'd had a really clear picture or style in his head and other times he'd say "No idea, what do you think?", I might offer, "I am hearing this is Dylan's Gospel phase-his amazing turn to Christ. Our show is set in the 1930s... leave it with me." So, I looked up some 1930s gospel songs and I found these beautiful quartets of these wonderful Kentucky 1930/1934 gospel singers and I just loved the way they moved and had a particular style and shape. I researched lots of videos and I just played until I found a language. Then, we stuck two songs on the end of it-"Señor" and "Is Your Love in Vain?" — and then we thought "This could be the funeral". And then we definitely didn't make a funeral!

We never make anything explicit, it's about the poetry of the images, the audience's interpretation. That particular moment in the show sticks out for me, as I am not exaggerating when I say we made that scene 10 times! We would watch it and think "Yes, that works" and the next day, we would watch it again and go "Ooh. No. That's just not right any more". And then, as the play shifted-and it was a dream that Conor was in the room as writer as well-he would just tell the actors "You can re-write it. Just fix it!"

That was so liberating, as a team, because Bob Dylan, also, was like that. In a sense, Bob Dylan is about truth and is not precious. I watched him in an interview and somebody asked "Why did you go electric, Bob?" and just he said "Why did YOU go electric?" He has this wonderful way of cutting through any nonsense of people trying to dig too deep-into understanding and unlocking-and trying to think "what did Bob mean?", trying to pin it down, rather than just experiencing it. Allowing something to be present-dancing together or communing together-or allowing a song to fly above a text for a moment, you don't understand why it's working, but it is, because the tone is just perfect or the placement is just perfect.

\section{GR: In what ways do you approach solo songs?}

LH: Again it's just about truth. In some of the solo songs, we thought that we could do with some of the company coming on and accompanying, but some I knew were never going to be 'numbers'. It was never going to be that show from day 1. Although, I didn't know that when I took the job! But I did know that it wasn't a show where the whole company came on and performed choreography facing out (except for one cheeky moment). In fact we spent so much time going "Stop facing out. Be with each other in a moment to move together and then we will come to you as an audience". 
The first time Sheila Atim stood up and sang "Tight Connection to My Heart (Has Anybody Seen My Love)" with a glass of milk in her hand, and we looked at each other and said "We are not going to mess with that. It' s perfect. It's perfect in every way." 1

And that has remained the way we do that number 3 years on. Because it's about someone standing in a moment and her world potentially crashing around her, feeling the pressure of everything that's arriving and just letting the song take her away for a moment. She did that performance of the Olivier Awards. It got the whole of the Royal Albert Hall to their feet for the first time in the whole evening and that was a very special thing to experience!

\section{GR: What differences were amongst the American and British casts?}

LH: Talking only about my experience on Girl from the North Country, the American casts are expected to be much more independent, so you are not asked to run a warm-up every day. They don't have a warm-up factored into a pre-show either. They have to turn up to rehearsals and turn up for the show warm. We are not liable in that way to ensure that their bodies and voices are warmed up, but I find it such a beautiful, communal thing to have everybody do a class together before a show or rehearsals. The American cast was saying that they really loved the half-hour class before the rehearsal, which is pretty standard in the UK.

I noticed that I had to tell the American cast "not to dance" much more than I had to tell the British cast, but I guess that is because of the casting. We had more musical theatre actors in the American cast than the British casts. That's about personalities and training. It definitely felt that the American casts understood the Dylan thing; it's in the fabric of who they are. The Dylan music is their parents' - and their own - childhood. They understand what he is singing about, even if they were not around when he was singing about it. They understand its history and it is interwoven into who they are. It was really moving working with them, and hearing their stories about the Great Depression and their grandparents' stories. It was very special to make a show about a place in the place.

GR: Do you use any improvisation, during performance, in your work?

$L H$ : I just love the fact that for the second half of Girl from the North, the actors are on stage and part of a massive party scene, bar one or two small scenes. All the action happening upstage is all improvised. And I have taught them five or six different dances they can do. It's the 1930s, "if your grandparents taught you a Turkey Trot, let me teach you how to do it". Some rehearsals were massive dance halls and they would develop characters: some who love to dance, and some who are terrible, there is a card game going on, there is a character who is always drunk; they have patterns and systems they can tap into. I suppose it's like being in the presence of a team of improvisers, but the structures are so strong and so set and foolproof. The actors are so attentive and present and so invested personally, so it's an incredibly precious thing to be part of, and I feel even if it ran for years, they would not have a stale experience. There is space for them to play and be present.

I have been making Girl from the North Country for nearly 4 years and I never tire of watching it. I cannot say that for many other shows I worked on.

GR: "Stop thinking like a dancer" is choreographer Daniel Ezralow's advice to dancers while working on Julie Taymor's remarkable film musical Across the Universe (2007). Director Julie Taymor wanted an approach of "using everyday movement as the vocabulary ... organically coming from naturalistic movement"! Do you agree with this? ${ }^{2}$

LH: It's a fear thing. It is amazing how dancers who have had training, and those who have not, the moment they start dancing, it's like they are doing choreography as opposed to movement.

\footnotetext{
https://www.youtube.com/watch?v=0grZUoUhn_k.

https://www.youtube.com/watch?v=W-KldtRgEkE.
} 
The brains kick into a performance mode. As soon as they start delivering movement, you get a very different experience of that, so I spend a lot of time telling actors "Stop dancing"!

\section{Working with Understudies/Swings: Injuries and Re-Workings}

\section{GR: How do you rehearse the understudies/swings?}

$L H$ : I have been really happy that understudies and swings I have worked with have all been incredibly studious. They come in and watch rehearsals from week 3 onwards, take thorough notes. In America, they were exceptional. Every night, you would see them, while the show was going on, not in their dressing rooms, but in the green room, or the corridor, doing the show with the live feed from the Tannoy.

In terms of rehearsing them, I take them a part at a time and see if there is anything they are unsure of. But it is hard.

\section{GR: How did you work on Local Hero in regard to the understudies and swings?}

LH: I remember a very dear actor, Matthew Malthouse, who has been my Associate on a few shows. While working on the stage musical version of Local Hero, he told me, "This process is a nightmare". My work is multi-layered and not easily replicated, I appreciate that. And if there are on-stage swings, I will try and use them as much as possible. Swings are understudies are so highly skilled. Incredible talent. They will often save and solve so many problems and offer solutions out of challenging situations. "How do we move this from here to here, and then do the quickest costume change?"

In terms of rehearsing them, I have been very lucky, they have done much of the work themselves: they are in the room, they are active, they are participating. Then they work with the assistant director. They are basically not learning my choreography, but the style of the actors they are covering. But, I am always very clear and honest with them, I do not want them to do an interpretation of the actor they are covering, but to find their own. Obviously, the steps have to be the same, because they have to fit into a structure, but I am very happy for them to put their own personality on it. If they have offerings for me, I will always take the time and go through it with them. And stand with them and move them, and make sure what they are doing fits in beautifully with the rest of the company.

There is space in my work for people to bring their individuality to it. They are very detailed and intricately choreographed shape-wise, but personality and style wise, there is always space for actors to be themselves. That is a risky business. You leave a show after a strict rehearsal period and tech, and then you go away. I have to trust that these actors have the space to move within the constraints of what I choreographed for them. Over the years I have been working, this has not backfired-nobody has taken advantage of that, and if they have, the rest of the company stood up and said "that is not what we are doing here". They do hold true to the safety of the structure of what I made and allow the performances to grow within it.

\section{GR: What motivates your movement material invention?}

LH: It depends on the show. If it's an opera, it's always the music, because that is the most poignant personality in the room. With Shakespeare, it's the language. But for me, it's always the actors I have in front of me. I love drawing out from them how their bodies can tell a story, and how they can use their specific set of skills to be truthful. We are all bodies. We are present in real life and in conversations and in drama. Sometimes, stripping it right back to those particular bodies we have in front of us is the most joyful experience.

\section{GR: How involved are you in the casting? Does each cast give you a specific opportunities/limitations?}

$L H$ : I am not often involved in casting. I often get asked if I would like to. But because now casting musicals sometimes involves casting actors and not specifically trained dancers, it's very seldom that I am needed to go in and do a movement call because I do not expect people to turn up and pick 
up choreography. I am interested in wonderful actors and interesting bodies and the dynamics and balance of those personalities and bodies on stage.

GR: How about injury? How do you deal with extended cases of injury in a cast?

$L H$ : We have had a fair amount of injury, not through negligence. It happens-actors lose their voices, hurt themselves. In extended cases of injury we tend to re-shape the choreography. While working on the musical The Last Ship, Sting himself tore his bicep in the middle of rehearsals, and I re-choreographed some moves for the other arm. It's about longevity and sustainability. From day 1 , the work I do with the actors is always about training, resilience and sustainability. I always ask them to drink water and warm up-reminding them that their bodies are their tools and they have to take care of them. It minimizes the amount of possible injuries we could have. But long term, we have re-cast before when the actor could not do that part anymore, or it's about re-working it so that they can continue.

\section{New Trends on Broadway}

GR: In Ivo Van Hove's West Side Story, Jerome Robbins's landmark choreography was replaced with new work by the Belgian avant-gardist Anne Teresa De Keersmaeker. According to Ben Brantley, the "choreography has aggressive accents of taekwondo and boxing, along with an air-slicing assortment of somersaults. Yet generally, these dancers seem less like kamikaze street warriors than scampering puppies, who like nothing more than to run around in circles and wriggle on their backs" (Brantley 2020). What did you think of it?

LH: I thought Anne Teresa De Keersmaeker's work was exquisite. The production is incredibly ambitious, beautifully dangerous and deserves its place on Broadway absolutely. I would not have wanted to take that role—of choreographer-on that show. I think if you will get somebody to come and re-do it, you get Anne Teresa De Keersmaeker. I have been a massive fan of her work since I was a student. Her work on West Side Story is unbelievable. The way she has taken the heart of the original choreography and made it beat for an audience today. There were elements of contemporary movement in there, as well as truth — the athleticism of the cast is unbelievable!

\section{GR: Any other inspirations?}

LH: Annie-B Parsons recently choreographed beautifully David Byrne's American Utopia, which is not even a musical. It's basically a gig - and she moves David and the band around the stage and it's unbelievable. If you see that show, you will see some real human people having a brilliant boogie, and having the best time. They move like people move in real life. They move like musicians move on stage. They move like people dance in their front rooms and that's not because they are moving badly, but they move in a very human, joyful, naturalistic way that's based in gesture-it's natural, truthful and exhilarating and we can all connect with it.

GR: In what ways did Steven Hoggett move the style towards a more abstract everyday movement language (in American Idiot, Once, Rocky)?

LH: Steven has been wonderfully present on Broadway and I have been inspired by him and his work. There is a call for truth. We are moving into a time where there is so much available to us to experience, not only theatre, but also television and social media, people are able to access real life and truth so much quicker. People are able to switch off more easily.

Audiences are looking for a way to connect deeply and there will always be space for shows which whisk us away to somewhere magical, or the more traditional choreography or structure. But there is a trend for using actors in musicals, very differently trained voices, and differently moving bodies, and I feel very fortunate that I have been part of a wave.

GR: Is there an invasion of British choreographers on Broadway? 
LH: It's a very international platform. A lot of shows went from the West End to Broadway and vice versa and there is a healthy exchange.

GR: In the controversial article 'The Performance of Discipline', Susan Russell writes about her experience working on The Phantom of the Opera that "The shift in time that was required of me in order to replicate eight different simulations eight times a week for five years created an actor that could achieve corporate theatre's goal of a circulating capital. I succeeded in replicating the past in order to ensure the future financial success of my producer and his investors. All I had to do was become a piece of machinery that was subject to the checks and balances of management. I have experienced a metamorphosis into a new age of performance, and my body is an archive of this political and economic mutation. Management's 'power over [my] active body', which was joined with 'an uninterrupted, constant coercion, supervising the processes of [my] activity rather than its result, [ ... ] assured the constant subjection of its forces and imposed on [me] a relation of docility-utility'" (Russell 2007, p. 106). How do you respond to this? How does dance affect mental health?

LH: I feel very lucky that the work I have done, and the shows I have made have not been that experience at all. Even if we are in the Broadway machine, we have a very unique show, and people keep telling me that. I have never had any pressure at any point to make my work exactly replicable - and that is risky, for financial reasons as well. The cost of Broadway is huge. I give much more autonomy to my actors than traditional musical structure and choreography. And there is some risk, if an actor is not well, or not able to deliver on a specific night. But, genuinely, I feel that the structures we put in place in the rehearsal room and the palette we give them-the choices, stamina and the training-makes them fully invested.

Russell talks about mental health here, and just delivering that choreography again and again and again, and yes, you get a clean product. But you also get people checking out, mentally. It must be a very exhausting and helpless place to go to if you are delivering something so highly structured, which is just about a product rather than an investment, and know that it's so structured that you can be so easily replaced. Whereas, in my work, I try to encourage autonomy and help actors feel like they are valued differently. I always want and expect that from actors I work with, and they give that back!

Conflicts of Interest: The author declares no conflict of interest.

\section{References}

Brantley, Ben. 2018. Review: 'Girl from the North Country' Sets the Darkness Aglow. New York Times. October 1. Available online: https://www.nytimes.com/2018/10/01/theater/girl-from-the-north-country-review-bobdylan.html (accessed on 22 April 2020).

Brantley, Ben. 2020. 'West Side Story' Review: Sharks vs. Jets vs. Video. New York Times. February 20. Available online: https://www.nytimes.com/2020/02/20/theater/west-side-story-review-sharks-vs-jets-vs-video.html (accessed on 22 April 2020).

Pattullo, Lauren. 2007. Narrative and spectacle in the Hollywood musical: contrasting the choreography of Busby Berkeley and Gene Kelly. Research in Dance Education 8: 73-85. [CrossRef]

Russell, Susa. 2007. The Performance of Discipline on Broadway. Studies in Musical Theatre 1. [CrossRef]

(C) 2020 by the author. Licensee MDPI, Basel, Switzerland. This article is an open access article distributed under the terms and conditions of the Creative Commons Attribution (CC BY) license (http://creativecommons.org/licenses/by/4.0/). 